\title{
KarjaKompassi käyttöön karjatilojen tuotannonohjauksessa
}

\author{
Virva Hallivuori $^{\left.{ }^{*}\right)}$, Tuija Huhtamäki ${ }^{1)}$, Marketta Rinne ${ }^{2)}$, Martin Lidauer $^{2}$, Tuomo Kokkonen ${ }^{3)}$ ja Juha \\ Nousiainen ${ }^{4)}$ \\ ${ }^{1)}$ ProAgria Keskusten Liitto, PL 251, 01301 Vantaa, etunimi.sukunimi@proagria.fi \\ ${ }^{2)}$ MTT, 31600 Jokioinen, etunimi.sukunimi@mtt.fi \\ ${ }^{3}$ Maataloustieteiden laitos, Kotieläintiede, 00014 Helsingin yliopisto, tuomo.kokkonen@helsinki.fi \\ ${ }^{4)}$ Valio Oy, PL10, 00039 Valio, juha.nousiainen@valio.fi \\ *Nykyinen osoite: Valio Oy, PL10, 00039 Valio,virva.hallivuori@valio.fi
}

\section{Tiivistelmä}

KarjaKompassi-kokonaisuuden kehittäminen ja sen taustalle tehty tutkimustyö ovat merkittävä panostus, joka on nyt saatu käyttöön suomalaisen maidontuotannon ja maitotilojen kilpailukyvyn kehittämiseksi. KarjaKompassi-palvelukokonaisuus on tehty karjatilojen tuotannonohjaukseen, jolla seurataan ja suunnitellaan ruokintaa, maidon- ja rehuntuotantoa ja sen taloutta. Uusien ohjelmistojen ja palveluiden avulla tutkimuksesta saatu tieto jalkautuu yksittäisten karjojen tasolle. KarjaKompassia on työstetty vuosina 2008-2011 projektissa, jossa olivat mukana ProAgria Keskusten Liitto ja ProAgria Laskentakeskus, Valio Oy, SLU, MTT, HY ja TTS. Suomen meijeriyhdistys ja TEKES ovat osallistujien lisäksi rahoittaneet projektia.

Ruokinnan suunnitteluun lähdetään KarjaKompassissa uudelta pohjalta. Työ aloitetaan lähtötilanteen huolellisella tarkastelulla Ruokinnan seurannan päivälaskelman avulla. Se otettiin käyttöön vuoden 2010 alussa ja sen perusteella voidaan arvioida ruokinnan onnistumista, tarvittaessa säätää ruokinta kohdalleen ja arvioida karjan vakiotuotos. Syksyllä 2011 otettiin käyttöön ruokinnan suunnittelu, joka on kiinteässä yhteydessä ruokinnan seurannan kanssa. Yhdessä ruokinnan seuranta ja suunnittelu muodostavat Ruokinnanohjauspalvelun, jossa analysoidaan laskelmista saadut tulokset ja havainnoidaan toteutuksen ongelmakohdat tilatasolla navetassa ja pellolla.

Ruokinnan taloudellisessa optimoinnissa KarjaKompassi huomioi ruokinnan muutosten taloudelliset vaikutukset rahatuloihin maidon määrän ja koostumuksen muutosten kautta. Valittavana on myös muita optimointiperusteita. Monipuoliset optimointimahdollisuudet ovat tarpeellisia, koska tuotantopanosten ja tuotteiden hinnat todennäköisesti vaihtelevat jatkossakin nopeasti ja niihin on pystyttävä tilatasolla reagoimaan.

Tuottoennuste-osio valmistuu talven 2011-2012 aikana. Tuottoennusteesta saadaan tietoa karjan tulevista eläinmääristä, maitotuotoksista sekä maidon pitoisuuksista, joiden perusteella voidaan arvioida maidosta saatava rahallinen tuotto vuosibudjetoinnin taustalle tai investointeja suunniteltaessa.

KarjaKompassi-kokonaisuuden avulla voidaan tarkastella erilaisia vaihtoehtoja maidontuotannon, kasvinviljelyn ja talouden näkökulmasta. Suunnitelmassa lähdetään liikkeelle siitä, että karja on pellon asiakas. KarjaKompassin nettipohjaisilla ohjelmilla tehdyt laskelmat tallentuvat ProAgrian tietopankkeihin, joissa on tietoa maitotilojen eläinaineksesta, maidontuotannosta, rehuvaroista, rehujenkulutuksesta ja ruokinta- ja lypsytekniikoista, sadoista sekä peltojen lannoituksesta. Näitä tietoja maitotilat voivat yhteisesti hyödyntää ProAgrian Tilakunnon kautta tekemällä erilaisia vertailuja.

Tässä kirjoituksessa esitellään KarjaKompassi-kokonaisuutta karjatilojen tuotannonohjauksen näkökulmasta ja uusia tutkimustuloksia, joihin se perustuu.

Asiasanat: lypsylehmä, maidontuotanto, ruokinnansuunnittelu, rehuarvo, vapaaehtoinen syönti, mallintaminen, optimointi 


\section{KarjaKompassi palvelee maitotiloja}

ProAgrian uudessa palvelukokonaisuudessa hyödynnetään KarjaKompassi-projektin aikana valmistuvia ohjelmistoja. KarjaKompassi-palvelukokonaisuus on tehty karjatilojen tuotannonohjaukseen, jolla seurataan ja suunnitellaan ruokintaa, maidon- ja rehuntuotantoa ja sen taloutta. Uusien ohjelmistojen ja palveluiden avulla tutkimuksesta saatu tieto jalkautuu yksittäisten karjojen tasolle. KarjaKompassia on työstetty vuosina 2008-2011 projektissa, jossa olivat mukana ProAgria Keskusten Liitto ja ProAgria Laskentakeskus, Valio Oy, SLU, MTT, HY ja TTS. Suomen meijeriyhdistys ja TEKES ovat osallistujien lisäksi rahoittaneet projektia.

Ruokinnan suunnitteluun lähdetään KarjaKompassissa uudelta pohjalta. Työ aloitetaan lähtötilanteen huolellisella tarkastelulla Ruokinnan seurannan päivälaskelman avulla. Se otettiin käyttöön vuoden 2010 alussa ja sen perusteella voidaan arvioida ruokinnan onnistumista, tarvittaessa säätää ruokinta kohdalleen ja arvioida karjan vakiotuotos. Syksyllä 2011 otettiin käyttöön ruokinnan suunnittelu, joka on kiinteässä yhteydessä ruokinnan seurannan kanssa. Yhdessä ruokinnan seuranta ja suunnittelu muodostavat Ruokinnanohjauspalvelun, jossa analysoidaan laskelmista saadut tulokset ja havainnoidaan toteutuksen ongelmakohdat tilatasolla navetassa ja pellolla.

Ruokinnan taloudellisessa optimoinnissa KarjaKompassi huomioi ruokinnan muutosten taloudelliset vaikutukset rahatuloihin maidon määrän ja koostumuksen muutosten kautta. Valittavana on myös muita optimointiperusteita. Monipuoliset optimointimahdollisuudet ovat tarpeellisia, koska tuotantopanosten ja tuotteiden hinnat todennäköisesti vaihtelevat jatkossakin nopeasti ja niihin on pystyttävä tilatasolla reagoimaan. Tuottoennuste-osio valmistuu talven 2011-2012 aikana. Tuottoennusteesta saadaan tietoa karjan tulevista eläinmääristä, maitotuotoksista sekä maidon pitoisuuksista, joiden perusteella voidaan arvioida maidosta saatava rahallinen tuotto vuosibudjetoinnin taustalle tai investointeja suunniteltaessa.

KarjaKompassi-kokonaisuuden avulla voidaan tarkastella erilaisia vaihtoehtoja maidontuotannon, kasvinviljelyn ja talouden näkökulmasta. Suunnitelmassa lähdetään liikkeelle siitä, että karja on pellon asiakas. KarjaKompassin nettipohjaisilla ohjelmilla tehdyt laskelmat tallentuvat ProAgrian tietopankkeihin, joissa on tietoa maitotilojen eläinaineksesta, maidontuotannosta, rehuvaroista, rehujenkulutuksesta ja ruokinta- ja lypsytekniikoista, sadoista sekä peltojen lannoituksesta. Näitä tietoja maitotilat voivat yhteisesti hyödyntää ProAgrian Tilakunnon kautta tekemällä erilaisia vertailuja.

Maataloustieteen Päivillä 2010 KarjaKompassi oli esillä omana sessiona (ks. Kyntäjä \& Rinne 2010), jolloin esiteltiin projektia ja siihen liittyviä tutkimustuloksia. Myös Lypsylehmien ruokinta oppaassa (ProAgria 2010) on kattavasti käyty läpi KarjaKompassin taustalla olevia lehmien ravitsemuksen ja hoidon periaatteita. Tässä kirjoituksessa esitellään KarjaKompassi-kokonaisuutta karjatilojen tuotannonohjauksen näkökulmasta ja uusia tutkimustuloksia, joihin se perustuu.

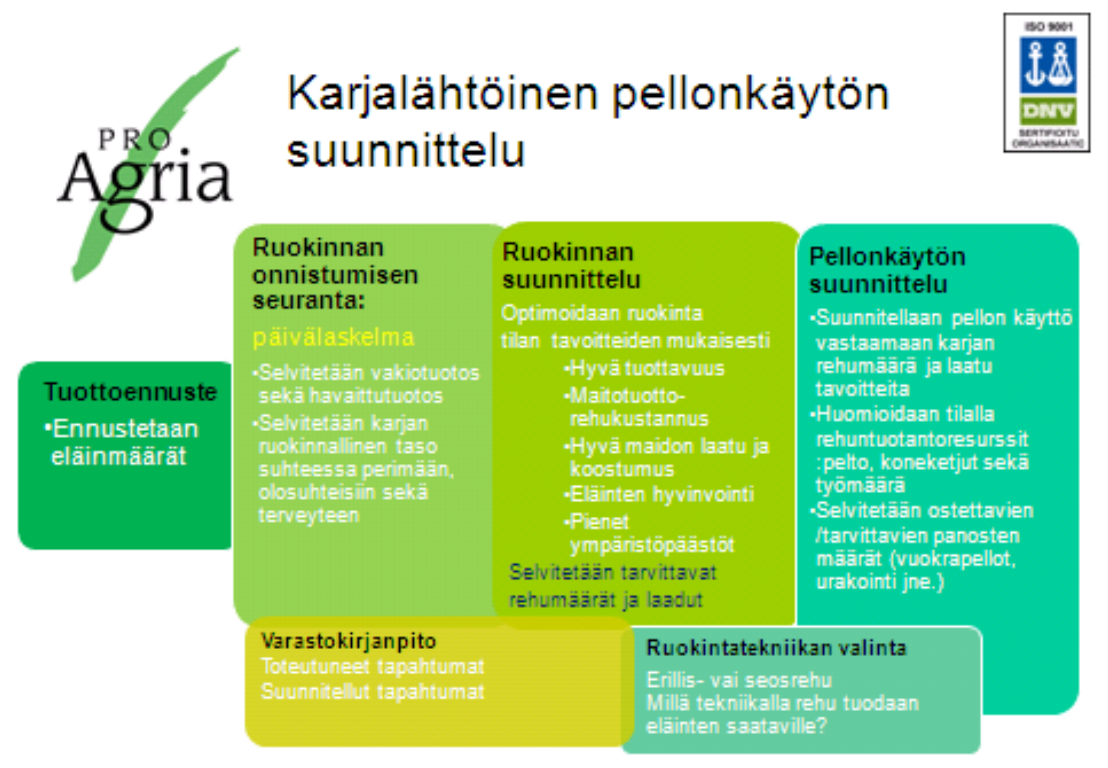

Kuva 1. Pellonkäytön suunnittelun tulee maitotilalla lähteä karjan tarpeista. 


\section{Uusi näkökulma ruokintaan}

KarjaKompassin ruokinnanohjaus otettiin ProAgriassa käyttöön syksyllä 2011. Uuden ajatusmallin vieminen tuotoksen mukaisesta ruokinnasta vapaaseen ruokintaan sekä yksilöruokinnasta eläinryhmäkohtaiseen ruokintaan vaatii rohkeutta niin maidontuottajilta kuin maitotilaneuvojilta. KarjaKompassin ruokinnan suunnittelun avulla voidaan nopeasti tehdä vertailuja kannattavimman karkearehun sekä täydennysrehujen valinnan tueksi. Investointitilanteessa ja eläinmäärien kasvaessa voidaan arvioida tulevaa peltoalan tarvetta ja viedä peltoalan tarve ja satojen laatutarve viljelyssuunnittelun ja rehunkustannuslaskelmien taustalle.

KarjaKompassin ruokinnansuunnitteluosio pohjautuu Lypsikki-malliin (Nousiainen ym. 2011, Huhtanen ym. 2011). Maitotuotos arvioidaan rehujen syönnin, ravintoaineiden saannin ja tuotosvasteyhtälöiden perusteella (Huhtanen \& Nousiainen, 2011). Näin pystytään arvioimaan ruokinnan muutosten vaikutukset maitomäärään ja maidon pitoisuuksiin ja sitä kautta maidosta saatavaan rahalliseen tuottoon sekä laskemaan ruokinnan taloudellisuus (maitotuotto miinus rehukustannus). Muutosten (=tuotosvasteet) mahdollisimman hyvä hallita on tärkein edellytys sille, että ruokinta voidaan optimoida taloudellisesti parhaiten kannattavaksi.

Ruokinnansuunnittelun optimointiperuste on käyttäjän valittavissa. Useimmiten optimointiperusteeksi valitaan maitotuoton ja rehukustannusten erotus euroina. Muitakin tavoitteita voi olla kuten esimerkiksi maksimi maitotuotos tai maidon valkuaispitoisuus, minimi rehukustannus tai ympäristönäkökulmasta minimi typpi- tai fosforipäästöt. Tuotantopanosten ja tuoteteiden hintojen nopeat muutokset saadaan hallintaan monipuolisilla optimointimahdollisuuksilla. Kun ruokintaa suunnitellaan Karjakompassilla käyttäen "maitotuotto miinus rehukustannusta" optimointiperusteena, ruokinnan intensiteetti asettuu sille tasolle, millä saavutetaan paras taloudellinen tulos, koska suunnittelun taustalla käytetään vaihtuvia ruokintasuosituksia. Intensiteetti voi siis vaihdella riippuen panosten (rehujen) ja tuotoksen (maidon) hintojen suhteesta.

\section{Ruokinnan seurannan päivälaskelman avulla selvitetään vakiotuotos}

Ruokinnan onnistumista seurataan päivälaskelmien avulla ja samalla määritetään lehmien tuotantopotentiaali eli vakiotuotos toteutuneen ruokinnan ja sillä saavutetun maitotuotoksen perusteella. Vakiotuotos kuvaa maitotuotosta vakioruokinnalla, jonka koko rehuannoksen syönti-indeksi (TDMI) on 100 pistettä ja rehuannoksen ohutsuolesta imeytyvän valkuaisen (OIV) pitoisuus $90 \mathrm{~g} / \mathrm{kg} \mathrm{ka}$. Vakiotuotoksen avulla eri karjat voidaan korjata "samalle viivalle" ruokinnan voimaperäisyyden suhteen.

Vakiotuotosta ja havaittua tuotosta vertaamalla voidaan päätellä, onko parannettavaa ruokinnassa vai karjan hoidossa, olosuhteissa, terveydessä tai perimässä. Jos vakiotuotos on selvästi havaittua tuotosta pienempi, käytössä on jo voimakas ruokinta ja ruokintaa tehostamalla on vaikea saavuttaa tuotoksen lisäystä. Lisäpanostuksia kannattaa todennäköisesti suunnata ennemmin eläinten olosuhteiden ja eläinaineksen parantamiseen. Jos taas vakiotuotos on suurempi kuin havaittu tuotos, voidaan ruokintaa (määrää tai laatua) parantamalla saavuttaa melko hyvä tuotosvaste.

Päivälaskelmia pitää tehdä riittävän usein, vähintään $4 \mathrm{kpl}$ ajoittuen tasaisesti ympäri vuoden, jolloin vuodenaikaisvaihtelut rehustuksessa ja poikimisten ajoittumisessa tasoittuvat. Haasteellista tilatasolla on arvioida eläinten syönti. Rehujen syöntiä arvioidaan navetassa ja rehujen varastotaseen avulla. Vapaasti syötetyn säilörehun kulutuksen mittaaminen on vaikeaa ja se voidaan myös laskennallisesti arvioida. Tuotosseurantatietojen oikeellisuus maitomäärän ja pitoisuuksien osalta vaikuttaa havaitun maitomäärän laskemiseen ja siten vakiotuotokseen. Mahdolliset virheet arvioinneissa on pyrittävä minimoimaan, sillä ne vaikeuttavat uuden ruokinnan optimoinnin onnistumista. Ennusteiden pohjana käytetyt kaavat edellyttävät hyviä lähtötietoja antaakseen luotettavia tuloksia.

\section{Suunnitelun pohjaksi tarvitaan luotettavat lähtötiedot}

Ruokinnan suunnitteluun tarvitaan tarkat tiedot käytettävissä olevista rehuvaroista. Säilörehusadon laadun ja määrän arviointiin on erityisesti paneuduttava (ks. Artturi 2011), mutta myös muista käytettävissä olevista rehuista tarvitaan tiedot saatavuudesta ja koostumuksesta rehuarvoineen. Kun kyseessä on taloudellinen optimointi, hintojen määrittely rehuille on aivan keskeistä ja hintamuutokset vaikuttavat voimakkaasti optimoinnin tuloksiin. 
Luotettavat tuotosseurannan ja ruokinnan seurannan tiedot ovat välttämättömiä. Päivälaskelmien avulla saadaan tieto karjan nykyisestä rehustuksesta, rehujen syönnistä ja näillä saavutettavasta maitotuotoksesta, jolloin karjan tuotantointensiteetistä saadaan käsitys ja voidaan laskea vakiotuotos. Yhtenä lähtötietona käytetään lehmien kokoa, joka vaikuttaa syöntiarvioon. Karjakohtaiset erot voivat olla suuria ja tietojen päivittämisestä on huolehdittava.

\section{Rehuarvojen ja ruokintasuositusten päivitys 2010}

Vuonna 2010 tehtiin merkittäviä päivityksiä märehtijöiden rehuarvoihin ja ruokintasuosituksiin. Ajantasaiset tiedot rehuarvoista ovat saatavissa MTT:n ylläpitämästä Rehutaulukot-verkkopalvelusta (MTT 2011). Valkuaisarvojen laskentaperusteita tarkasteltiin laajaan maidontuotantokoeaineistoon perustuen (Huhtanen 2010). Muutosten seurauksena valkuaisarvojen laskentaa pystyttiin hieman yksinkertaistamaan ja silti parantamaan järjestelmän kykyä ennustaa maitovalkuaisen tuotos. Uudessa laskentatavassa mikrobivalkuaisen tuotanto ennustetaan rehun sulavan orgaanisen aineen määrän (D-arvo) ja hvo-arvon (hajoavan valkuaisen osuus) perusteella. Raakakuidun ja raakarasvan määrityksiä ei siis enää valkuaisarvojen laskentaan tarvita ja väki- ja karkearehujen valkuaisarvot lasketaan samoja kaavoja käyttäen.

Mikrobivalkuaista muodostuu $152 \mathrm{~g}$, kun rehusta tulee $1000 \mathrm{~g}$ substraattia (D-arvo miinus ohitusvalkuainen). Kerroin on hieman aikaisempaa pienempi, mikä johtaa suurempaan PVT-arvoon. Nyt siis PVT-arvot ovat aiempaa paremmin kohdallaan ja lypsylehmillä tulee pyrkiä siihen, että ruokinnan PVT-arvo on positiivinen. Samassa yhteydessä nostettiin aminohappojen osuus mikrobivalkuaisesta 0.75:een (aikaisemmin 0.70) ja painotetaan aikaisempaa enemmän OIV:n kertymää rehujen ohitusvalkuaisesta. Jälkimmäisen merkitys on siinä, että pystytään paremmin eriyttämään rehujen energiaja valkuaisarvoja toisistaan. Niiden välillä on edelleenkin selkeä yhteys johtuen mikrobivalkuaisen suuresta merkityksestä märehtijän valkuaisen saannissa.

Energia-arvojen perusteisiin ei tehty muutoksia eli energia-arvona käytetään edelleen alun perin brittiläisen laskentatavan mukaan ilmaistua muuntokelpoista energiaa (ME). Tässä yhteydessä luovuttiin kuitenkin ME:n ilmoittamisesta rehuyksiköinä ja sen tilalle otettiin yleisesti käytetty energian yksikkö megajoule (MJ). Aiemmin megajoulet muunnettiin rehuyksiköiksi jakamalla megajouleina ilmoitettu MElukema vakiolla 11,7.

Valkuais- ja energiasuositukset ja energiansaannin korjausyhtälö päivitettiin laajaan maidontuotantokoeaineistoon perustuen. OIV:n tarve maidontuotantoon muuttui siten, että maitovalkuaisgrammaa kohti tarvittava OIV-määrä pienenee tuotoksen suurentuessa. Tällä tavalla voidaan epäsuorasti huomioida valkuaisaineenvaihdunnassa tapahtuvia muutoksia, joita sellaisenaan on vaikea liittää laskentaan. Tuotostason noustessa kuiva-aineen syönti kasvaa ja rehun viipymäaika pötsissä lyhenee. Tällöin rehun sulavuus hieman laskee ja ohitusvalkuaisen osuus kasvaa. Energian saanti suhteessa valkuaisen saantiin siis pienenee, vaikka rehuannoksen koostumus pysyisi samana.

Energian saannin korjausyhtälön avulla korjataan rehujen ylläpitotasolla ilmoitettujen energiaarvojen toteumaa lypsylehmillä siten, että kuiva-aineen syönnin lisääntyminen pienentää sulavuutta eli energia-arvoa ja vaikutus on sitä suurempi, mitä suurempi käytettyjen rehujen energiapitoisuus on ylläpitotasolla eli Rehutaulukoissa ilmoitetussa muodossa. Rehuannoksen valkuaispitoisuuden suurentuminen puolestaan käyräviivaisesti parantaa sulavuutta (Nousiainen ym. 2010).

\section{Syöntimallit luovat pohjan lehmien vapaaehtoisen syönnin ennustamiselle}

Energian saanti on tärkein yksittäinen lehmien maidontuotantoon vaikuttava tekijä ja siihen vaikuttaa aivan keskeisesti lehmien vapaaehtoinen syönti. Lähdemme lehmien ruokinnassa liikkeelle oletuksesta, että rehuja on tarjolla vapaasti. Toteutuvaan syöntiin vaikuttavat karkearehun laatu ja väkirehuruokinta, eläimen ominaisuudet ja ympäristötekijät. KarjaKompassin taustalla on syöntimalli, jossa on toisistaan riippumattomasti otettu huomioon eläin- (vakiotuotos, elopaino) ja rehuperäiset (säilörehun ja väkirehun syönti-indeksit) syöntiin vaikuttavat tekijät, mikä on maailmanlaajuisestikin merkittävä edistysaskel ruokinnansuunnittelussa. Maailmalla yleisesti käytössä olevat mallit ennustavat syönnin havaitun tuotoksen perusteella. Ne selittävät syönnin hyvin, mutta ongelma on se, että tieto on optimoinnin kannalta liian myöhään käytettävissä. Havaittua tuotosta ei myöskään voida käyttää samassa mallissa rehun laadun 
kanssa, koska eläimen syöntiin vaikuttaa sen tuotospotentiaali rehun laadun lisäksi. Tästä johtuen karjan vakiotuotos on selvitettävä mahdollisimman tarkasti ennen uuden ruokinnan suunnittelua.

Säilörehun laatutekijöiden vaikutukset rehun suhteelliseen syöntipotentiaaliin voidaan arvioida säilörehun syönti-indeksin avulla (Huhtanen ym. 2007, Rinne ym. 2008, ks. myös ARTTURI®verkkopalvelun Laskurit-sivu). Säilörehun syöntipotentiaalia parantavat korkea sulavuus (D-arvo), rajoittunut käyminen ja pieni kuitupitoisuus. Kuiva-ainepitoisuuden vaikutus on käyräviivainen siten että korkeimmillaan syönti on, kun kuiva-ainepitoisuus on n. 420 g/kg. Kesän ensimmäisestä sadosta tehdyn rehun syöntipotentiaali on jonkun verran parempi kuin loppukesän rehujen ja karkearehujen monipuolistaminen käyttämällä nurmipalkokasveja tai kokoviljasäilörehua lisäävät syöntiä.

Väkirehuruokinnan vaikutuksia säilörehun vapaaehtoiseen syöntiin ja sitä kautta koko rehuannoksen syöntiin on niin ikään mallinnettu (Huhtanen ym. 2008). Kokonaissyönti lisääntyy, kun väkirehuannos suurenee, mutta vähemmän kuin väkirehuannos kasvaa, koska samalla säilörehun vapaaehtoinen syönti vähenee. Tätä kuvataan korvaussuhteella, joka on käyräviivainen eli kokonaissyönnin kasvu hidastuu väkirehuruokinnan voimistuessa.

Väkirehun valkuais- ja kuitupitoisuuden suureneminen ja hajoavan valkuaisen osuuden pieneneminen lisäävät säilörehun vapaaehtoista syöntiä, mutta väkirehun rasvapitoisuuden suureneminen hieman vähentää sitä. Säilörehun syönti-indeksillä ja väkirehumäärällä on lisäksi yhdysvaikutusta eli väkirehuruokinnan lisääntyminen vähentää kokonaissyöntiä enemmän, kun perusrehuna käytetyn säilörehun syöntipotentiaali on suuri. Suhteelliset säilörehun ja väkirehun syönti-indeksit yhdistämällä pystytään ilmaisemaan koko rehuannoksen suhteellinen syöntipotentiaali.

\section{Yksilökohtaisesta normiruokinnasta karjan kokonaisuuden hallintaan}

KarjaKompassin ruokinnansuunnittelussa painotetaan karjan ruokintaa kokonaisuutena eli liikkeelle lähdetään koko karjan ja koko tuotantokauden mittaisesta ruokinnan optimoinnista. Laskennallisissa tarkasteluissa tarkemmasta jaottelusta ei ole saatu hyötyä. Lähestymistapa sopii erityisen hyvin seosrehuruokintaan. Ohjelmistossa on mahdollista optimoida ruokinta erikseen lypsykauden alkuvaiheessa oleville lehmille, jolloin voidaan esimerkiksi valita käytettäväksi eri rehuja. Optimoitu rehuannos voidaan myös jakaa suhteellisesti ruokintaluokkiin, mutta tällöin rehuannoksen koostumus pysyy kaikissa luokissa samoina. Koetulokset osoittavat, että melko yksinkertainen ruokintamalli toimii hyvin ja esim. valkuaisrehujen tasainen käyttö lypsykauden aikana antaa keskimäärin yhtä hyvän maitotuotoksen kuin tuotoksenmukainen rehunjako, ja tuottaa tasaisemman lypsykäyrän (Mäntysaari ym. 1995).

Karjan maidontuotanto ennustetaan ns. tuotosvasteyhtälöiden perusteella (Huhtanen \& Nousiainen 2011). Muuntokelpoisen energian ja rehuperäisen ohitusvalkuaisen saanti selittävät suurimman osan maitotuotoksen vaihtelusta, mutta siihen vaikuttavat lisäksi ohitusvalkuaisen, rehuannoksen solunsisällyshiilihydraattien ja rasvan pitoisuudet. Tuotosvasteyhtälöt on laskettu erikseen maidolle, energiakorjatulle maidolle ja valkuaistuotokselle ja ne poikkeavat hieman toisistaan. Rasvatuotos lasketaan erotuksena olettaen maidolle vakio laktoosipitoisuus. Vähenevän lisätuoton lain mukaisesti lisävaste ravintoaineiden saannille pienenee, jos intensiteetti jo lähtötilanteessa on korkea.

Ruokinnansuunnittelussa ei huomioida lehmien energiataseessa tapahtuvia muutoksia. Lypsykauden alkuvaiheessa lehmät käyttävät kudosvarastojaan ja loppulypsykaudella taas täydentävät niitä. Niemelän (2011) aineistossa vanhempien lehmien keskimääräinen energiatase oli negatiivisin (noin $50 \mathrm{MJ} / \mathrm{pv}$ ) lypsykauden toisella viikolla, jolloin se vastasi laskennallisesti lähes 10 maitokilon tuottamiseen tarvittavaa energiamäärää. Yksittäisillä lehmillä tase saattoi olla vielä negatiivisempi, jopa yli kaksinkertainen. Ensikoiden energiavaje lypsykauden alussa on pienempi kuin vanhempien lehmien. Niemelän (2011) aineistossa ensikoiden keskimääräinen energiatase lypsykauden toisella viikolla oli -25 $\mathrm{MJ} / \mathrm{pv}$.

Lehmien keskimääräinen energiatase oli negatiivinen 14 viikon ajan poikimisesta. Keskimääräisten viikoittaisten energiataseiden perusteella lehmät tuottivat kudoksista tulevan energian avulla noin $450 \mathrm{~kg}$ maitoa. Olettaen $9000 \mathrm{~kg} /$ vuosi keskimääräinen tuotos, kudosvarastojen avulla tuotetun maidon osuus vuosituotoksesta oli n. $5 \%$. Vaikka kohtuullinen kudosmobilisaatio on luonnollinen ja normaali ilmiö, runsas kudosmobilisaatio ja syvä energiavaje lisäävät lehmien hedelmällisyys- ja terveysongelmia (Kokkonen ym. 2010). 
KarjaKompassin ruokinnanoptimointi perustuu lehmäryhmien koko maidontuotantokauden keskimääräiseen tuotantoon. Se ei siis sovellu yksittäisen huippulehmän ruokinnan hetkelliseen tarkasteluun sellaisenaan. Tuotosvasteyhtälöt on estimoitu aineistosta, jossa kokeessa olleiden ruokintaryhmien maitotuotos oli vähintään 25 kg/pv. Aineiston luokittelu eritasoisiin lehmäryhmiin on osoittanut, että tuotostasolla ei ole merkittävää vaikutusta toteutuviin vasteisiin.

Yksittäinen huippulehmä voi lypsää huomattavasti enemmän, mihin tyypillisesti osaselityksinä vaikuttavat lehmän keskimääräistä suurempi koko ja maidon pieni energiapitoisuus eli matalat rasva- ja valkuaispitoisuudet. Lisäksi tällaisen lehmän syöntikyky ja kudosvarastojen purkamiskyky todennäköisesti ovat keskimääristä suuremmat. Maidontuotannon talouden kannalta keskeisintä on kuitenkin keskittyä koko karjan tarkasteluun ja mahdollisimman taloudelliseen ja rationaaliseen ruokintaan.

\section{Tuottoennuste ennakoi karjan tulevia tapahtumia}

Tuottoennusteen avulla voidaan arvioida karjan eläinmäärän kehitystä seuraavien 12 kk aikana, joka riittää pohjaksi rehutarpeiden laskentaan seuraavalle ruokintakaudelle. Tuottoennusteesta saadaan ennusteet maitotuotokselle ja maidonrasva- ja valkuaispitoisuudelle. Tuottoennuste lasketaan Pohjoismaisen jalostusarvostelun tilastollisen mallin ratkaisuiden perustella. Malli ottaa kaikki Suomessa tehdyt mittalypsyhavainnot vuodesta 1988 asti huomioon ja mallittaa kaikki tärkeimmät ympäristö- ja eläintekijät. Ympäristö- ja eläintekijänratkaisujen hyödyntämistä varten käytetään MTT:ssä kehitettyjä filttereitä kuten karja-, yleis-, eläin- sekä polveutumisfiltterit. Jokaisesta filtteristä tulee omat käyrät, jotka laskuri kokoaa eläinkohtaiseksi ennusteeksi (Pitkänen ym. 2011).

Tuottoennusteella arvioidaan lehmien ja ensikoiden tulevaa tuotosta ja lasketaan maitotuotoksen pohjalta saatava tulo , joten siitä on hyötyä investointeja suunniteltaessa. Tuottoennusteen laskentalogiikkaa voisi käyttää arvioitaessa maidontuotannon kehittymistä myös alueellisella tai valtakunnallisella tasolla. Tuottoennusteiden luotettavuus paranisi, jos tuotosseurantatietojen viiveitä pystyttäisiin lyhentämään, sillä ne vaikuttavat pohjoismaisista NAV-jalostusarvosteluista saataviin tuloksiin.

\section{Energiataseen ja nurmisadon mallinnus mahdollistavat KarjaKompassin jatkokehityksen} KarjaKompassi-projektiin kuului tutkimustehtäviä, jotka luovat pohjaa uusien elementtien lisäämiseen KarjaKompassi-ohjelmiston uusiin versioihin. Näitä ovat lehmien energiataseen mallinnus ja nurmen kasvun mallintaminen.

Energiataseen mallinnus perustuu aikaisempien tuotantokokeiden aineistoihin ja tarkoituksena on mallintaa, mitkä tekijät vaikuttavat lehmien energiataseeseen. Malleissa käytettävät selittävät muuttujat ovat koeolosuhteissa tai tilatasolla mitattavissa. Työssä on testattu malleja, joilla ennustetaan energiatasetta joko ennen lypsykauden alkua tai lypsykauden aikana käytettävissä olevien tietojen perusteella. Malleissa huomioidaan poikimisesta kulunut aika, koska se on selvästi vahvin yksittäinen energiatasetta selittävä tekijä. Ennen lypsykauden alkua käytettävissä olevat tiedot ovat lähinnä rehujen/ruokinnan koostumustietoja ja syönti-indeksejä sekä elopaino- ja kuntoluokkatietoja. Lypsykauden aikana on näiden lisäksi käytettävissä tiedot maitotuotoksesta ja maidon koostumuksesta.

Tällä hetkellä pystytään energiatase mallintamaan suhteellisen hyvin maidontuotannon alkuvaiheessa karjatasolla. Energiatasemalleilla ei pystytä ennustamaan yksittäisen lehmän energiatasetta. Ruokinnallisista tekijöistä energiatasetta selittävät parhaiten väkirehun ja rehuannoksen syönti-indeksit sekä väkirehun osuus ruokinnassa. Energiakorjattu maitotuotos selittää hyvin energiatasetta, mutta sen käyttökelpoisuutta rajoittaa lypsykauden alkuvaiheen maitotuotos- ja maidonkoostumustietojen saatavuus. Energiataseen mallinnuksesta on valmistunut maisterintutkielma (Niemelä 2011).

Nurmirehujen tuotannon hallinta sisältäen mm. korjuustrategian, lannoitus- ja kasvilajivalinnat on yksi karjatilan menestyksen edellytyksistä. Nurmisadon määrän ja laadun ennustamiseen säätietojen perusteella on kehitetty malleja (Rinne ym. 2010), joita hyödynnetään mm. ARTTURI® Korjuuaikatiedotuksen taustalla (Artturi 2011). Nurmen kehitys 1. sadossa on nopeampaa ja yhdenmukaisempaa kuin 2. sadossa. Nurmentuotannon malleja voitaneen jatkossa käyttää simuloitaessa rehuntuotannon tarpeita määrän ja laadun sekä peltoalan suhteen tilakohtaisten ominaisuuksien puitteissa. 


\section{Kirjallisuus}

Artturi. 2011. ARTTURI® verkkopalvelu. Saatavilla: www.mtt.fi/artturi

Huhtanen, P. 2010. Märehtijöiden valkuaisarvojärjestelmä (OIV-PVT) uudistuu. Maataloustieteen Päivät 2010. Saatavilla: www.smts.fi/jul2010/esite2010/013.pdf

Huhtanen, P. \& Nousiainen, J. 2011. LYPSIKKI - a novel approach for the formulation of dairy cow rations. Nordic Feed Science Conference, 15-16 June 2011. Uppsala, Sweden. Available at: www.slu.se/PageFiles/66523/NFSC2011_Proceedings2.0.pdf

Huhtanen, P., Rinne, M. \& Nousiainen, J. 2007. Evaluation of the factors affecting silage intake of dairy cows: a revision of the relative silage dry-matter intake index. Animal 1: 758-770.

Huhtanen, P., Rinne, M. \& Nousiainen, J. 2008. Evaluation of concentrate factors affecting silage intake of dairy cows: a development of the relative total diet intake index. Animal 2: 942-935.

Huhtanen, P., Rinne, M., Mäntysaari, P. \& Nousiainen, J. 2011. Integration of the effects of animal and dietary factors on total dry matter intake of dairy cows. Animal 5: 691-702.

Huhtanen, P., Nousiainen, J. \& Turtola, E. 2011. Dairy farm nutrient management model: 2. Evaluation of different strategies to mitigate phosphorus surplus. Agricultural Systems 104: 383 - 391.

Kokkonen, T., Mäntysaari, P. \& Huhtanen, P. 2010. Lypsylehmän energiataseen mallintaminen. Maataloustieteen Päivät 2010. Saatavilla: www.smts.fi/jul2010/esite2010/015.pdf.

Kyntäjä, J. \& Rinne, M. 2010. Ruokinnan suunnittelu uudistuu - KarjaKompassi työvälineeksi. Teoksessa: . Anneli Hopponen (toim.). Maataloustieteen Päivät 12.-13.1.2010. Suomen maataloustieteellisen seuran tiedote 26: 4 s. Saatavilla: www.smts.fi/jul2010/esite2010/012.pdf

MTT. 2011. Rehutaulukot ja ruokintasuositukset [verkkojulkaisu]. Jokioinen: MTT Maa- ja elintarviketalouden tutkimuskeskus. Saatavilla: http://www.mtt.fi/rehutaulukot.

Mäntysaari, P., Huhtanen, P., Nousiainen, J. \& Virkki, M. 2005. The effect of protein-feeding strategy during lactation on performance of primiparous dairy cows fed total mixed ration. Livestock Production Science 94: 189198.

Niemelä, K. 2011. Lypsylehmän energiataseen mallintaminen tuotoskauden alkuvaiheessa. Maisterintutkielma. Helsingin yliopisto, Maataloustieteiden laitos. 59 s. Saatavilla: helda.helsinki.fi/handle/10138/28244.

Nousiainen, J., Rinne, M. \& Huhtanen, P. 2010. Rehuannoksen koostumus ja ruokintataso vaikuttavat lypsylehmien rehuannoksen sulavuuteen. Maataloustieteen Päivät 2010. Saatavilla: www.smts.fi/jul2010/esite2010/014.pdf

Nousiainen, J., Tuori, M., Turtola, E. \& Huhtanen, P. 2011. Dairy farm nutrient management model. 1. Model description and validation. Agricultural Systems 104: 371-382.

Pitkänen T., Mäntysaari E.A., Rinne M. \& Lidauer M. 2011. Animal-wise prediction of milk, protein and fat yield using solutions from the Nordic test-day model. EAAP 2011, Stavanger, Norway. Available at: www.eaap.org/Stavanger/Stavanger_Book_of_Abstracts.pdf

ProAgria 2010. Lypsylehmien ruokinta. Tieto tuottamaan 133. ProAgria Keskusten Liiton julkaisuja nro 1096. 131 s. Rinne, M., Huhtanen, P. \& Nousiainen, J. 2008. Säilörehun ja koko rehuannoksen syönti-indeksit auttavat lypsylehmien ruokinnan suunnittelussa. Maataloustieteen Päivät 2008. Saatavilla:

www.smts.fi/mpol2008/index_tiedostot/Esitelmat/es086.pdf

Rinne, M., Pitkänen, T., Nyholm, L., Nousiainen, J. \& Huhtanen, P. 2010. Alkukesän nurmikasvuston sulavuuden ja sadon määrän mallit nurmirehuntuotannon hallintaan. Maataloustieteen Päivät 2010. Saatavilla: www.smts.fi/jul2010/poste2010/136.pdf 